\title{
30. PALEONTOLOGICAL RESULTS FROM OCEAN DRILLING PROGRAM LEG 101 ${ }^{1}$
}

\author{
David K. Watkins ${ }^{2}$ \\ With contributions from \\ Eric Fourcade, ${ }^{3}$ R. Mark Leckie, ${ }^{4}$ Allan J. Melillo, ${ }^{5}$ Amanda A. Palmer, ${ }^{6}$ Joost W. Verbeek, ${ }^{7}$ Jacques Butterlin, ${ }^{8}$ \\ Renée Damotte, ${ }^{9}$ Claude Guernet, ${ }^{10}$ Edwige Masure, ${ }^{11}$ and Michael J. Moran ${ }^{2}$
}

\begin{abstract}
Leg 101 of the Ocean Drilling Program recovered Albian through Holocene sediments from a variety of carbonate depositional environments. Data from four microplanktonic groups (calcareous nannofossils, planktonic foraminifers, radiolarians, and dinoflagellates) and four benthic groups (larger foraminifers, smaller benthic foraminifers, ostracodes, and sponge spicules) yield a biostratigraphic and paleoecologic framework for these varied sediments. Winnowed, skeletal-planktonic foraminiferal packstones and grainstones from the central Straits of Florida (Site 626) reflect a late Oligocene to Holocene history of sporadic sedimentation greatly influenced by strong bottom-current activity. Neogene to Quaternary sediments from two carbonate-slope transects (Sites 627 to 633) indicate significant slope accretion and progradation during the latest Miocene through early Pliocene, erosion and/or nondeposition during part of the late Pliocene, and slower accretion and slope progradation during the Quaternary. The Turonian through late Oligocene of the Little Bahama Bank area (Sites 627 and 628 ) was characterized by sporadic pelagic carbonate sedimentation punctuated by lengthy hiatuses in sediment accumulation, indicating sediment starvation and low surface-water productivity. Brief periods of siliceous biogenic sedimentation in the northwestern Bahamas during the late Oligoceneearly Miocene, middle Eocene, and late Campanian are expressions of temporarily higher surface water fertility and productivity. Uppermost Albian through middle Cenomanian hemipelagic marly limestones at Site 627 (Little Bahama Bank) record an upward-deepening sequence developed over a drowned upper Albian shallow-water carbonate platform. Bathyal middle to upper Albian organic-rich marly chalks in Northeast Providence Channel (Site 635) indicate that a deep-water channel existed there at approximately the same time that shallow-water carbonate-platform conditions prevailed north of Little Bahama Bank (Site 627).
\end{abstract}

\section{INTRODUCTION}

Leg 101 of the Ocean Drilling Program drilled 11 sites in the northern half of the Bahamian archipelago (Fig. 1). Sites 629 and 636 were abandoned soon after drilling began and are not discussed here. At other sites, the sediments recovered span the Albian through Holocene. These sediments, with few exceptions, contain various fossils that allow biostratigraphic dating and paleoecologic interpretation of depositional environments. This paper synthesizes information on these various fossil groups and constructs a coherent biostratigraphic and paleoenvironmental framework with which the mid-Cretaceous through Holocene history of the study area can be deciphered.

\footnotetext{
${ }^{1}$ Austin, J. A., Jr., Schlager, W., et al., 1988. Proc. ODP, Sci.Results, 101: College Station, TX (Ocean Drilling Program).

2 Department of Geology, 330 Bessey Hall, University of Nebraska, Lincoln, NE 68588-0340.

${ }^{3}$ UA 319 CNRS, Laboratoire de Stratigraphie, Université Pierre et Marie Curie, 4 Place Jussieu, 75252 Paris, France.

${ }^{4}$ Department of Geology and Geography, University of Massachusetts, Amherst, MA 01003.

5 Chevron, U.S.A., 935 Gravier Street, New Orleans, LA 70114.

6 Ocean Drilling Program, Texas A\&M University, College Station, TX 77843.

${ }^{7}$ Rijks Geologische Dienst, Spaarne 17, Postbus 157, 2000 AD Haarlem, The Netherlands.

8 UA 215 CNRS, Institut de Physique du Globe, 4 Place Jussieu, 75252 Paris, France.

${ }^{9}$ Unité associée au Centre National de la Recherche Scientifique no. 319 et Laboratoire de Micropaléontologie de l'Université Pierre et Marie Curie, Paris $\mathrm{V}^{\circ}$., France.

${ }_{10}$ Département de Géologie Sédimentaire, t. 15, 4 Place Jussieu, F-75230 Paris Cedex 05, France.

${ }^{11}$ Laboratoire de Micropaléontologie, U.A. 319, Université Pierre et Marie Curie, 4 Place Jussieu, 75252 Paris, France.
}

\section{NEOGENE AND QUATERNARY}

Upper Cenozoic material was recovered at all 11 sites drilled during Leg 101 (Fig. 1). Significant recovery of upper Cenozoic material was limited to Sites $626,627,628,630,631,632$, and 633; therefore, only these seven sites are discussed. Biostratigraphic assignment of the Neogene and Quaternary material was based largely on calcareous nannofossils (Watkins and Verbeek, this vol.) and planktonic foraminifers (Melillo, this vol.). Radiolarians add valuable biostratigraphic data on the Miocene at Sites 627 and 628 (Palmer, this vol.). Paleoecological interpretations are based on these fossil groups as well as on Miocene sponge spicules from Sites 627 and 628 (Palmer, this vol.) and ostracodes from Site 628 (Guernet and Fourcade, this vol.). Ostracodes, sponge spicules, and larger foraminifers (Fourcade and Butterlin, this vol.) yield information on transportation and redeposition of sediment from the carbonate platform onto the slopes.

Biostratigraphic assignments for these sediments are summarized in Figure 2. In general, age determinations for the upper Miocene through Quaternary material were severely limited by the poor state of fossil preservation (primarily calcite overgrowths) and the dilution of pelagic skeletal material by platform-derived debris. In several intervals, specific zonal and/or subzonal assignments could not be made. As a result, age determinations for some intervals are unusually broad, but they should not necessarily be interpreted as indicating long periods of uninterrupted sedimentation.

\section{Quaternary}

The uppermost Pleistocene to Holocene Emiliania huxleyi nannofossil zone was encountered at all seven sites. Only Sites 632 and 633 appear to contain complete chronostratigraphic 


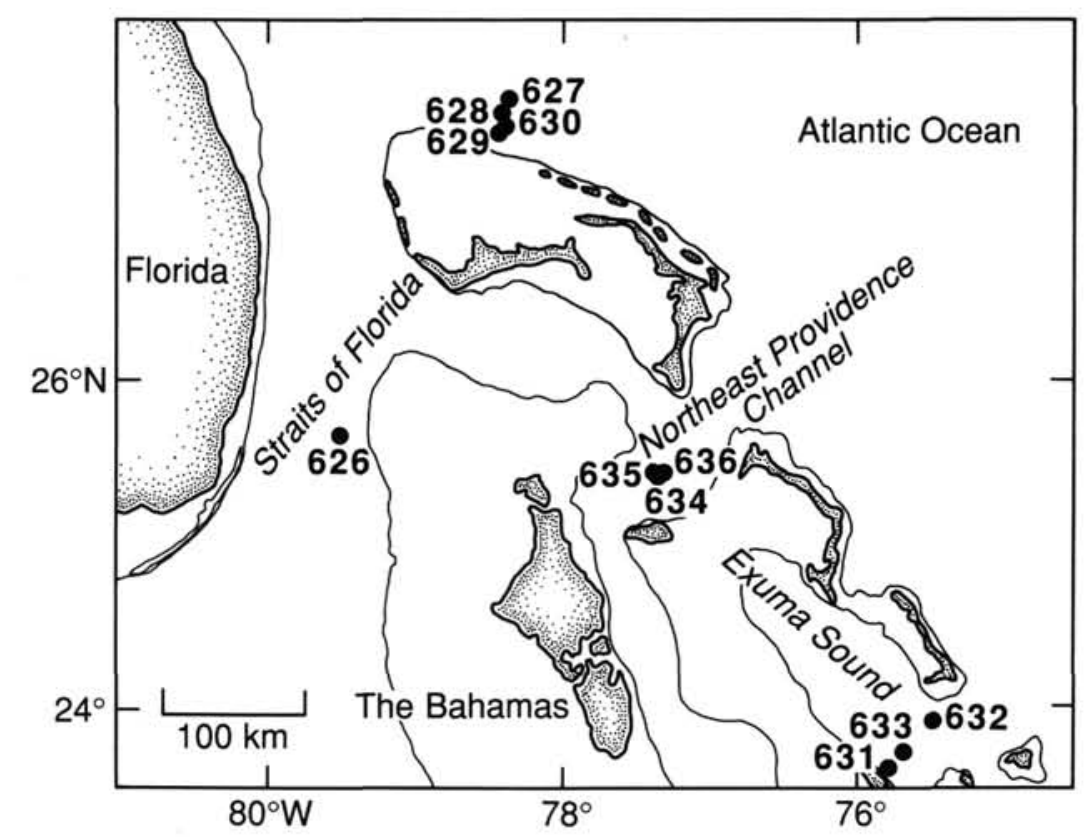

Figure 1. Site locations, ODP Leg 101.

records of the Pleistocene. At Site 632, preservation prevents exact delineation of all Pleistocene calcareous nannofossil or planktonic foraminiferal subzones, although all zones appear to be represented. At Site 633, nannofossils, planktonic foraminifers, magnetostratigraphic data, and oxygen isotopes all indicate a complete Pleistocene section (Droxler et al., this vol.). At other sites, the lower and middle Pleistocene is represented by thin, discontinuous sequences of periplatform ooze (such as at Sites 627 and 631) or is totally absent (Site 628). At Sites 626 and 630, the Pleistocene record is difficult to decipher owing to poor core recovery (Site 626), poor microfossil preservation (both sites), downhole contamination of younger microfossils (Site 626), and/ or reworking of older microfossils (both sites).

\section{Neogene}

A significant disconformity appears within the upper Pliocene of the entire study area. This disconformity (approximately correlative with the Globorotalia tosaensis planktonic foraminiferal zone) is the only unconformity that can be demonstrated to have such regional extent. At Sites 626, 628, and 633, this disconformity extends above or below the $G$. tosaensis Zone, whereas at other sites it seems confined largely to that zone. Melillo (this vol.) speculates that this regional disconformity may have resulted from erosion during the sea-level highstand of the TB3.7 cycle of Haq et al. (1987), although other factors may be involved.

Preservation of the remainder of the Pliocene record varies among the sites. No confirmed Pliocene samples were recovered from Site 626 (Straits of Florida). This may be an artifact of sample spacing or drilling difficulties, or it may be indicative of strong erosion by bottom currents in the Straits of Florida that either removed or prohibited deposition of the Pliocene sediments. At other sites, the general pattern is a relatively thin upper Pliocene and a much thicker lower Pliocene. This trend is well demonstrated along both the carbonate-slope transects, where the early Pliocene seems to have been a time of largescale slope progradation. Relatively thick sequences of periplatform chalk with a small pelagic component are typical of the lower Pliocene from both the Little Bahama Bank slope and the Exuma Sound slope. Microfossil preservation in these periplatform sediments is generally very poor, although brief periods of low platform influx resulted in purer pelagic sediments yielding reliable age indicators.

The high sedimentation rates of the early Pliocene (Austin, Schlager, et al., 1986) were apparently a continuation of a major progradational episode that began during the late Miocene. Thick sequences of periplatform chalk and limestone from Sites 630 (Little Bahama Bank transect) and 632 (Exuma Sound transect) attest to significant off-bank transport of predominantly fine-grained carbonate debris, which often swamped the pelagic components. Thin horizons (generally $<1 \mathrm{~m}$ thick) richer in pelagic microfossils permit biostratigraphic zonation, but even these horizons contain microfossils that are moderately to poorly preserved. The periplatform sediments often include platformderived ostracodes and larger foraminifers as reworked or redeposited material (Fourcade and Butterlin, this vol.). At Site 628, redeposited neritic ostracodes are relatively common throughout the Neogene sequence, when periplatform deposition and slope accretion were actively occurring. They are often associated with sediment gravity flow deposits. Penecontemporaneous redeposition of larger neritic foraminifers (such as Amphistegina) is fairly common throughout this thick sequence of periplatform sediments. Reworking of much older larger foraminifers (such as lepidocyclinids reworked into the upper Miocene) indicates erosion of older platform sediments and mobilization of this sediment onto the prograding platform slopes. Both redeposited and reworked larger foraminifers are associated with sediment gravity flow deposits. In general, neritic ostracodes and smaller neritic benthic foraminifer are more common than larger foraminifers in the periplatform sediments. Samples often contain redeposited ostracodes but not larger foraminifers, suggesting that these sediments were derived largely from the outer neritic (shelf) environment as opposed to the shallow-water platform. Only sediments containing both redeposited ostracodes and larger foraminifers contain material derived from the platform itself (Guernet and Fourcade, this vol.). Reworking of older pelagic units is also indicated by the nearly ubiquitous presence of Oligocene(?) nannofossils in the younger periplatform sediments.

All holes on the Exuma Sound transect (Sites 631 through 633) and Site 630 of the Little Bahama Bank transect terminated in the uppermost Miocene to lower Pliocene. As a result, 


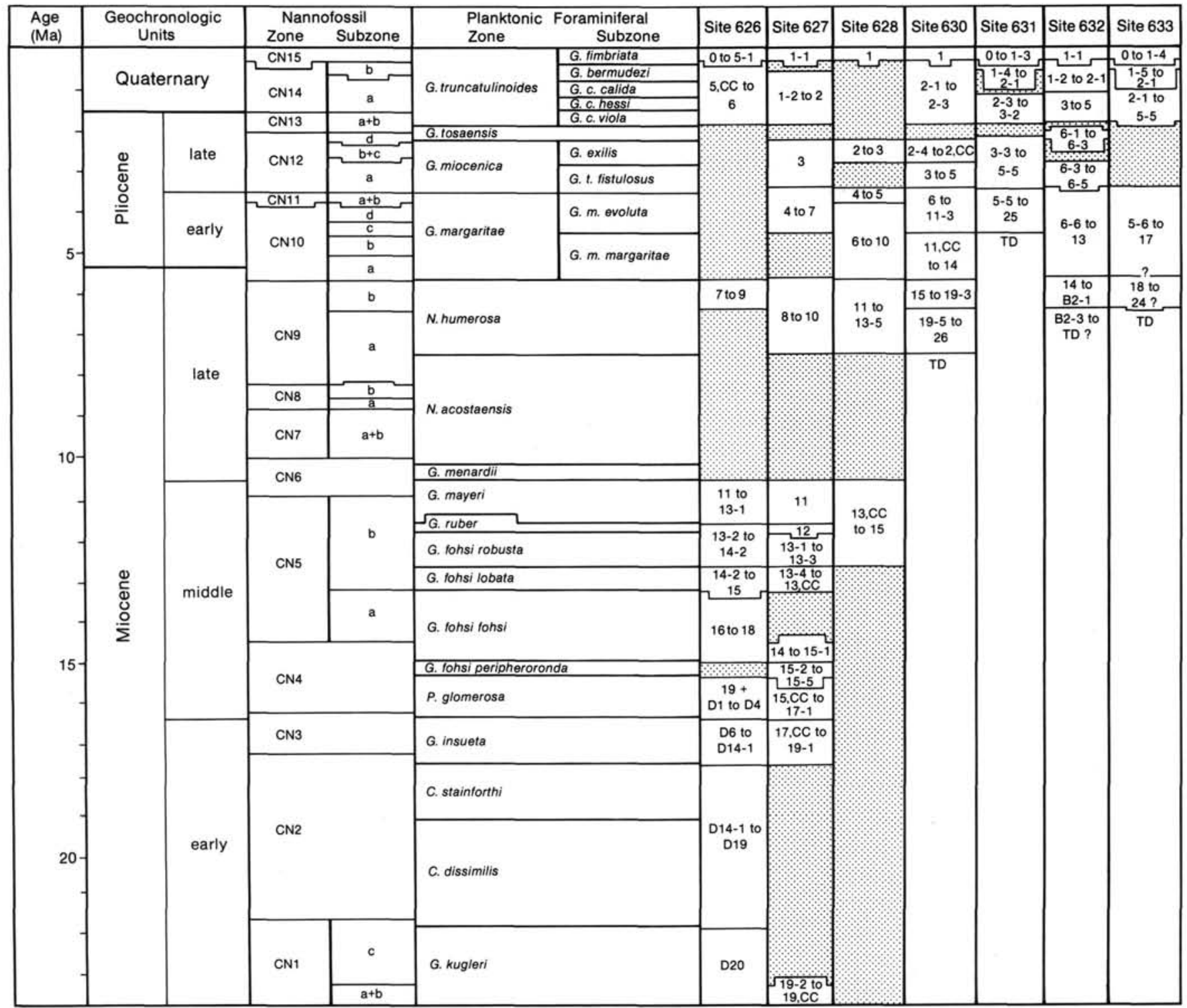

Figure 2. Summary of biostratigraphic assignments for Neogene and Quaternary sediments, ODP Leg 101. Correlation of calcareous nannofossil and planktonic foraminiferal zones after Berggren et al. (1985a). Stippled areas symbolize hiatuses associated with demonstrated unconformities. Numbers in columns refer to core and/or section numbers. Single numbers indicate core numbers (e.g., $5=$ Core 5 for that hole) whereas hyphenated numbers indicate core number followed by section number (e.g., 5-4 = Section 4 of Core 5 for that hole). For Site 626 , results from two holes were combined to yield a composite section (see text); cores from Hole $626 \mathrm{D}$ are indicated by a $D$ preceding the core number.

interpretation of the geologic record for most of the Miocene is based on evidence from Sites 626, 627, and 628. Most of the Miocene material from Site 626 consists of skeletal, planktonic foraminiferal grainstone and packstone, which implies substantial sediment winnowing by bottom currents. Calcareous nannofossil assemblages are sparse and poorly preserved. Planktonic foraminifers indicate a significant unconformity in the upper Miocene (approximately equal to nannofossil Zones CN6 to CN8; Fig. 2). The middle Miocene appears relatively continuous: only one planktonic foraminiferal zone ( $G$. fohsi peripheroronda) is not represented. Sediment gravity-flow deposits occur within the middle to upper Miocene of Site 627 and have been correlated with the Great Abaco Member of the Blake Ridge Formation (Austin, Schlager, et al., 1986; Fulthorpe and Melillo, this vol.). Microfossils indicate that the clasts were derived from several horizons in the lower to middle Miocene.
The early Miocene record may also be relatively complete, although poor preservation in the interval from Section 101626D-14X-1 through Core 101-626D-19X prohibits precise biostratigraphic placement. The record at Site 627 is more discontinuous, containing at least three prominent unconformities. A similar late Miocene ( $\approx \mathrm{CN} 6$ to $\mathrm{CN} 8$ ) period of nondeposition/ erosion is evident at Site 627. In addition, a middle Miocene hiatus equivalent to nannofossil Subzone CN5a is present. Most of the lower Miocene appears to be missing, only the uppermost lower Miocene and basal Miocene being represented in the stratigraphic record. At Site 628 the record is even more fragmentary: only a brief period of the middle Miocene ( $G$. fohsi lobata through $G$. mayeri foraminiferal zones) is represented by sediment. Radiolarians are common in the lower to middle Miocene sediment at Sites 627 and 628 . Their occurrence suggests relatively high surface-water productivity in this area during the 
early and middle Miocene. Palmer (this vol.) speculates that this may be a reflection of the topographically induced coastal upwelling invoked by Riggs (1984) to explain widespread phosphatic sediment deposition in the Miocene of North Carolina.

\section{PALEOGENE}

In-situ Paleogene material was encountered at Sites 626, 627, 628 , and 634 . Holes at Sites 626 and 628 terminated within the Paleogene. A small, displaced block of upper Paleocene material was encountered in an upper Neogene canyon-fill sequence at Site 635. Biostratigraphic assignment of the Paleogene material was based largely on data from calcareous nannofossils (Watkins and Verbeek; Moran and Watkins, this vol.) and planktonic foraminifers (Austin, Schlager, et al., 1986). Radiolarian data are also available from the upper Paleogene of Site 628 (Palmer, this vol.). Biostratigraphic assignments for the Paleogene material are summarized in Figure 3. Paleoecological interpretations are based on data from microplanktonic fossils (cited above) and benthic foraminifers (Austin, Schlager, et al., 1986), ostracodes (Guernet and Fourcade, this vol.), and sponge spicules (Palmer, this vol.). Important data on reworked and/or redepos- ited larger foraminifers are from Fourcade and Butterlin (this vol.).

\section{Oligocene}

Oligocene material was recovered from three sites, 626, 627, and 628. At two of these sites (626 and 627), drilling complications resulted in poor recovery of the Oligocene section. Only uppermost Oligocene (CP19b) sediment was penetrated at Site 626 , where poor recovery limits interpretation. The small amount of sediment recovered consists mainly of unlithified foraminiferal packstone. This well-winnowed sediment suggests active bottom-current activity, most probably from Gulf Stream flow through the Straits of Florida during the latest Oligocene. The Oligocene record from Site 627 is even poorer; here, the only evidence of Oligocene sediment consists of small fragments of white chalk mixed with Quaternary unlithified packstone (a downhole contaminant) and silicified limestone fragments of late Eocene age. Penetration of the Eocene silicified limestones and associated cherts probably resulted in the rest of the sediment being washed out of the core barrel. The uppermost Oligocene unit (CP19b) must have been less than $9.6 \mathrm{~m}$ thick (the cored inter-

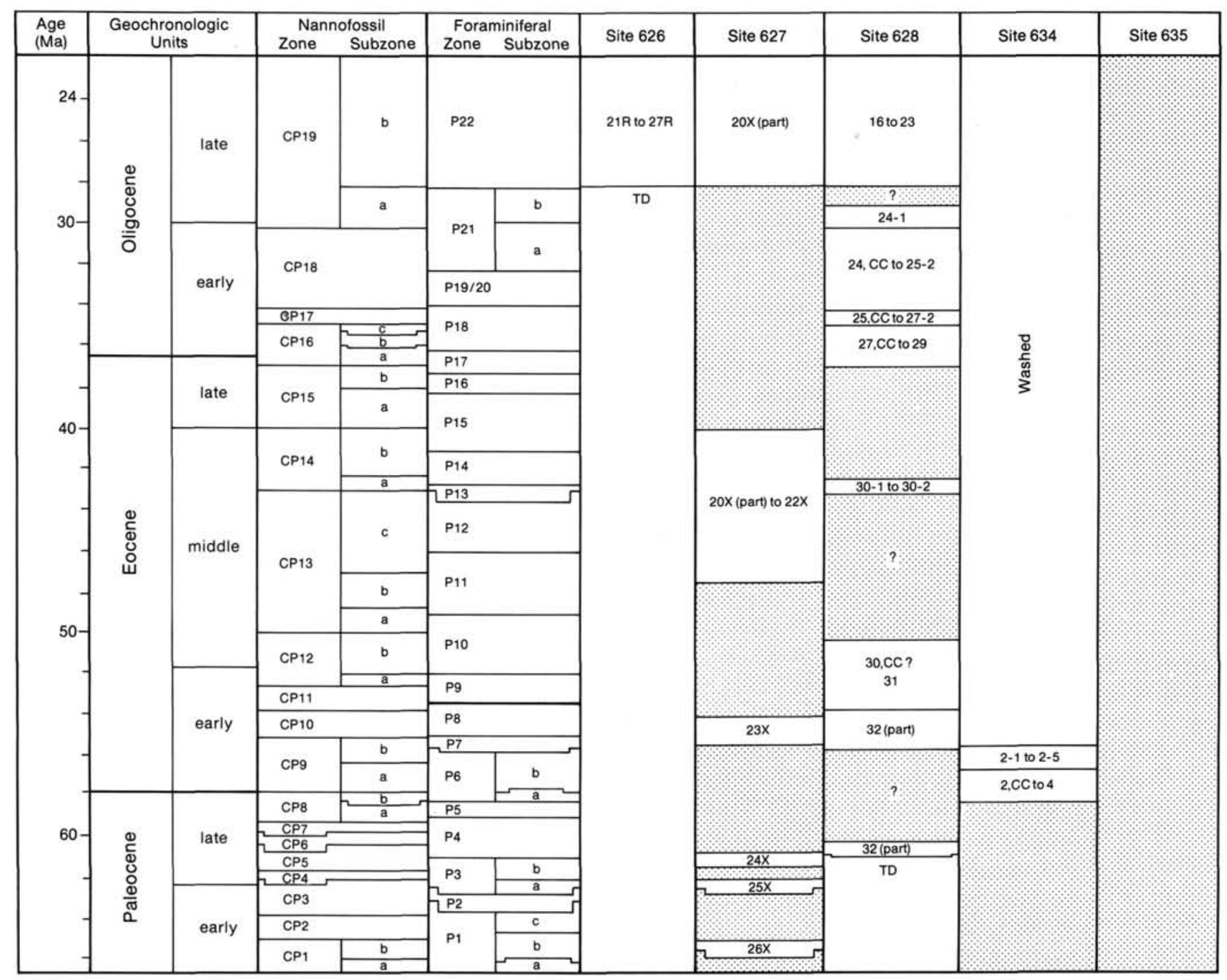

Figure 3. Summary of biostratigraphic assignments for Paleogene sediments, ODP Leg 101. Correlation of calcareous nannofossil and planktonic foraminiferal zones after Berggren et al. (1985b). See Figure 2 for symbols. 
val), but little else can be deduced from the scant evidence (Watkins and Verbeek, this vol.).

A much better record of Oligocene sedimentation was recovered from Site 628. A 133-m-thick sequence of pelagic ooze and chalk spans most of the Oligocene, and only one significant unconformity is present. This unconformity encompasses planktonic foraminiferal Subzone P21b. All other Oligocene calcareous planktonic microfossil zones and subzones are represented. The abundant and well-preserved calcareous planktonic microfossil assemblages indicate generally unrestricted oceanic conditions in the overlying surface waters during the Oligocene. The abundance of pentalith calcareous nannofossils at the base of the Oligocene sequence suggests some neritic influences in the surface waters over the site, although these may be (at least in part) a reflection of unstable oceanic conditions associated with the Eocene-Oligocene oceanic extinction event(s). Radiolarians in the upper portion of the sequence suggest relatively higher near-surface fertility during the latest Oligocene. Benthic foraminifers, ostracodes, and sponge spicules all indicate deep-water deposition during the Oligocene and little influx of platformderived material at the site. However, the relative proximity of a carbonate-platform environment is attested to by occasional occurrences of abraded neritic ostracodes and lepidocyclinids.

The upper Paleogene section at Site 634 was washed, so no direct evidence of the Oligocene was recovered. At nearby DSDP Site 98 , approximately $5.8 \mathrm{~m}$ of upper Oligocene foraminifernannofossil ooze was recovered in Core 98-11-98-5 before $28 \mathrm{~m}$ of section was drilled and washed. Wilcoxon (1972) reports Sphenolithus ciperoensis but not Sphenolithus distentis, suggesting that the ooze is from calcareous nannofossil Subzone CP19b (latest Oligocene). Thus, it appears that the latest Oligocene was a period of pelagic calcareous (and siliceous) biogenic sedimentation over much of the northwestern Bahamas.

\section{Eocene}

Eocene sediments were recovered from Sites 627, 628, and 634 , although the Site 634 record is incomplete. In general, sedimentation appears to have been sporadic during the Eocene, as indicated by unconformities. A thin record of the latest Eocene was recovered from Site 628, encompassing less than one core. A small quantity of middle Eocene material was recovered at Sites 627 and 628, but it is unrepresentative of the entire middle Eocene sequence, as drilling problems caused by nodular chert severely hampered recovery. This chert, however, indicates that the high siliceous productivity associated with horizon $\mathbf{A}^{\mathrm{c}}$ was well developed in the study area. Early Eocene sedimentation was also sporadic, and little record survives. Thin units of lower Eocene calcareous pelagic sediment are preserved at Sites 627 , 628 , and 634.

\section{Paleocene}

Paleocene sediments were recovered from Sites 627 and 628 . Little can be said of the Paleocene record recovered from Site 628. A small quantity of marly ooze of late Paleocene age (CP6) occurred in the core catcher of the basal core at this site. At Site 627, Cores 101-627B-24X through 101-627B-26X contained Paleocene material (Fig. 3). Each is of a different calcareous nannofossil zone (CP5, CP4, and CP2, respectively), but poor recovery makes it impossible to ascertain whether sedimentation was sporadic or merely slow through this interval.

\section{CRETACEOUS}

Cretaceous strata were penetrated and recovered from Sites 627,634 , and 635 (Fig. 1). Biostratigraphic assignment of the Cretaceous material was based largely on calcareous nannofossil (Watkins and Verbeek, this vol.) and planktonic foraminiferal (Austin, Schlager, et al., 1986) data, although dinoflagel- lates (Masure, this vol.) and ostracodes (Damotte, this vol.) provide some constraints on the important mid-Cretaceous sequence recovered from Hole 627B. Biostratigraphic assignments for the Cretaceous, based on data compiled from all microfossil groups, are summarized in Figure 4. Paleoecological interpretations are based on the previously mentioned groups as well as on shipboard studies of benthic foraminifers (Austin, Schlager, et al., 1986).

\section{Maestrichtian}

No Maestrichtian material was recovered from drilling during Leg 101. The unconformity encompassing the Maestrichtian varies in magnitude across the study area. In the northernmost Bahamas (southern Blake Plateau), as represented by Site 627 , this unconformity encompasses the lower Paleocene, Maestrichtian, and uppermost Campanian(?). At Site 634 (Northwest Providence Channel) a similar unconformity encompasses almost all of the Paleocene in addition to the Maestrichtian and uppermost Campanian. Similar results were reported from nearby DSDP Site 98 (Hollister, Ewing, et al., 1972) and from the northern Atlantic by Cepek et al. (1985). A much more profound unconformity (mid-Pliocene through Cenomanian) is evident in the axis of Northeast Providence Channel (Site 635).

\section{Campanian}

Campanian sediments were recovered from two Leg 101 sites, 627 and 634 . Sedimentary records at these two sites are quite different. Site 627 contains an abbreviated section of pelagic Campanian chalk. The Quadrum trifidum and Quadrum sissinghi calcareous nannofossil zones and the Globotruncanita calcarata and Globotruncana ventricosa planktonic foraminiferal zones are represented in the sequence from Cores 101-627$27 \mathrm{X}$ to $101-627 \mathrm{~B}-34 \mathrm{X}$, indicating a late Campanian age for this material. The overlap of these zones allows a threefold biostratigraphic subdivision of this sequence (Fig. 4). Sedimentation seems to have been relatively continuous throughout this brief interval, as suggested by the approximate sediment accumulation rate of $25 \mathrm{~m} / \mathrm{m}$.y. (Austin, Schlager, et al., 1986). This rate is well within the range expected for such calcareous pelagic sedimentation and implies no significant hiatus within the sequence. Microfossil preservation within the sequence is good to moderate, minor redistribution of calcite by etching and overgrowth being the most prevalent diagenetic effect (see Watkins and Verbeek, Plate 3, Figs. 1-2, this vol.). The presence of both calcareous nannofossils and planktonic foraminifers suggests a normal oceanic surface-water mass in the area during this part of the Late Campanian.

The paleontological record of the Campanian at Site 634, on the other hand, is longer yet more sporadic and indicates wider fluctuations in paleoenvironment. All three planktonic foraminiferal zones and at least five of the seven calcareous nannofossil zones of the Campanian are represented in the Site 634 material (Fig. 4). Only the lowermost Campanian Calculites obscurus nannofossil zone is absent from the recovered core material. Even this zone may be present at the site, as Hole 634A was terminated in the overlying $A$. parcus/C. ovalis combined nannofossil zone. Pentaliths are unusually common throughout most of this interval, suggesting neritic influences in the surface-water mass. However, poor recovery $(\approx 4 \%)$ limits interpretation of this interval.

It is clear that two vastly different lithologies are present. The planktonic microfossil assemblages generally occur within thin beds of bioturbated nannofossil chalk. At least some of these chalk beds contain nodules of light gray chert (Cores 101634A-18R and 101-634A-19R). These chalk beds are intercalated between beds of lithified rudstones and grainstones with rare boundstones and floatstones. The coarse carbonates are com- 


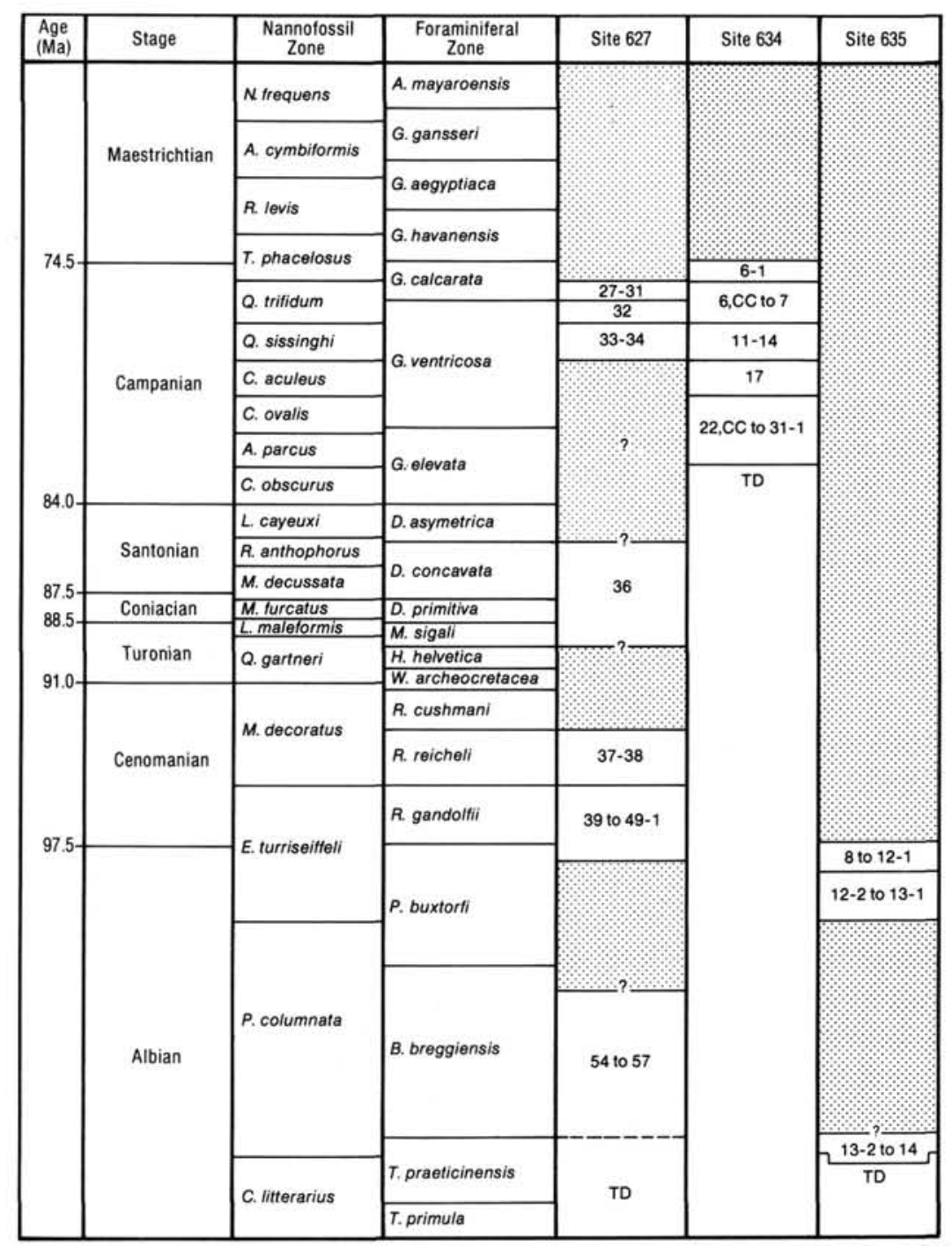

Figure 4. Summary of biostratigraphic assignments for Cretaceous sediments, ODP Leg 101. Correlation of calcareous nannofossil and planktonic foraminiferal zones modified from Bolli et al. (1985). Albian and Cenomanian planktonic foraminiferal zones after Leckie (1984). Geochronologic assignment of stage boundaries after Palmer (1983). Age determinations for Cores 101-627B-54X through 101-627B-57X based on dinoflagellate and ostracode taxon range and larger foraminifers shipboard; correlation with calcareous nannofossil and planktonic foraminiferal zones is approximate.

posed of a relatively wide assortment of carbonate-platform skeletal material, including grains derived from rudists, other bivalves, gastropods, encrusting and larger foraminifers, echinoids, and corals. Some also include clasts of deeper water sediments such as chert and chalk. These sediments must have been emplaced at the site by episodic sediment gravity flows that continued throughout the Campanian. However, at least some of these coarse carbonates were lithified in situ, whereas others may have been lithified on the platform before transportation to the basin (Austin, Schlager, et al., 1986). Graded bioclastic sand (unlithified) and nannofossil ooze were recovered from this interval at nearby DSDP Site 98 (Hollister, Ewing, et al., 1972), suggesting a greater degree of lithologic heterogeneity in the Campanian of this area than was indicated by Leg 101 drilling.

Unfortunately, the poor recovery at Site 634 makes it impossible to measure the relative abundance of sediment gravity-flow deposits and pelagic sediment directly. Extrapolation from sediment-accumulation rates for this interval (Austin, Schlager, et al.,
1986) suggests that pelagic chalk and ooze may dominate the upper Campanian section, whereas platform-derived sediment gravity-flow deposits dominate the lower Campanian section. Regardless, it is clear that Site 634 was on a platform slope underlying marginal oceanic surface waters during the Campanian.

\section{Late Cenomanian-Santonian}

Only Sites 627 and 635 penetrated a section older than the Campanian. Information on late Cenomanian through Santonian history is limited to Site 627 , however, as this record was removed from Site 635 by post-Cretaceous erosion. Interpretation is further impeded by poor recovery of this chronostratigraphic interval at Site 627. Core 101-627B-35X contained only material derived from downhole contamination. Core 101-627B-36X recovered $>1 \mathrm{~m}$ of fragmented, pale yellow, bioturbated limestone with common phosphatic and glauconitic pellets. Abundant calcispheres characterize this lithology. No age-diagnostic nannofossils were isolated from these sediments. Occurrence of 
the planktonic foraminifers Marginotruncana sigali (as Globotruncana sigali in Austin, Schlager, et al., 1986), M. coronata, and $M$. tarfayaensis in a sample fro Core 101-627B-36X indicates a late Turonian to early Santonian age for this interval. Occurrences of moldic porosity and phosphatic and glauconitic pebbles and lithologic differences between host rock and burrow fillings (Austin, Schlager, et al., 1986) in Core 101-627B-36X material suggest the presence of a hardground. On the basis of available evidence, therefore, it appears that the Turonian through Santonian was characterized largely by nondeposition and/or erosion at Site 627 and hardground formed during (at least) the late Turonian to early Santonian.

\section{Albian-Middle Cenomanian}

Holes at two sites, 627 and 635 , penetrated the mid-Cretaceous. The primary goal of drilling at both sites was penetration of a prominent acoustic horizon inferred to mark the top of a drowned and buried lower Cretaceous carbonate platform (Austin, Schlager, et al., 1986). Penetration of this horizon was achieved only at Site 627 , leaving some doubt as to the nature of the similar horizon at Site 635. It is clear, however, that paleontologic and lithologic records recovered from these two sites indicate major differences in the sedimentary history of these two localities during the mid-Cretaceous.

Mid-Cretaceous sediments at Site 627 are divisible into two stratigraphic units: an upper hemipelagic chalk and marly chalk sequence and a lower shallow water dolostone and gypsum unit (lithostratigraphic Units V and VI, respectively, of Austin, Schlager, et al., 1986). The upper chalk unit is rich in calcareous nannofossils and, to a lesser degree, in planktonic foraminifers, which provide age control for this interval. The dinoflagellate assemblages are sparser and lack the necessary marker taxa to allow correlation with established zonations. As a result, dinoflagellate age determinations are based upon known ranges of taxa that are not recognized zonal indicators. Ostracode age determinations are based on similar age-range criteria. There is general agreement, however, on the biostratigraphic sequence as established by the calcareous microplankton fossils (Fig. 4). Cores 101-627B-37X and 101-627B-38X can be confidently assigned to the middle Cenomanian based on all microfossil groups. Abundant Pithonella occur within this interval. The section from Core 101-627B-39X through Section 101-627B-49X-1 (base of lithostratigraphic Unit V) spans the lower Cenomanian and may include the uppermost Albian. Calcareous nannofossil analysis suggests that the base of this sequence is at or slightly below the Albian/Cenomanian boundary. Planktonic foraminiferal assemblages suggest a latest Albian through early Cenomanian age, the absence of Planomalina buxtorfi implying that the interval is entirely early Cenomanian. However, the possibility of paleoenvironmental (rather than biostratigraphic) exclusion of $P$. buxtorfi was considered (Austin, Schlager, et al., 1986). The nature of the ostracodes also suggests that the entire interval is Cenomanian. Correlation of dinoflagellate taxa suggests placement of the Albian/Cenomanian boundary between Section 101-627B43X-6 and 101-627B-46X-5, the interval from Section 101-627B$46 \mathrm{X}-5$ through 101-627B-49X-1 being latest Albian. Several paleoecological indicators (e.g., Pithonella abundance, planktonic to benthic foraminiferal ratios, paucity of keeled planktonic foraminifers, abundance of juvenile planktonic foraminifers, and nature and diversity of the benthic foraminiferal and ostracode assemblages) suggest an environmental change from inner-middle neritic conditions at the base of this section to the outer neritic (upper slope?) conditions evident in the middle Cenomanian section. This can best be interpreted as progressive deepening of the site during the early Cenomanian.

The underlying lithostratigraphic Unit VI consists of shallow water platform sediments dominated by dolostones and gypsum with lesser dolomitized skeletal limestone containing miliolid foraminifers (Austin, Schlager, et al., 1986). Biostratigraphy is based on shipboard identifications of larger foraminifers, dinoflagellate taxon ranges, and ostracode taxon ranges. All three criteria indicate a late (but not latest) Albian age for the platform sequence (Cores 101-627B-50X through 101-627B-57X). There is little evidence of a hiatus between cessation of platform sedimentation and inception of hemipelagic sedimentation. Ostracodes from Section 101-627B-53X, CC are monotaxic and suggestive of an inner neritic environment. Benthic foraminifers in Section 101-627B-52X, CC consist of miliolids, textularids, and larger foraminifers, which are typical of a shallow water, back-reef environment. These paleoecological indicators, in combination with the gypsum and cryptalgal(?) dolomites, indicate deposition in a restricted, back-reef lagoonal environment.

Drilling at Site 635 recovered a 57-m-thick sequence of midCretaceous organic-rich chalk and sediment gravity flow deposits. The sequence is separated into two biostratigraphic packages by an unconformity that does not correspond to a prominent lithologic boundary. Core 101-635B-8R through Section 101-635B-13R-1 contains two calcareous nannofossil subzones (the upper Prediscosphaera spinosa and lower Hayesites albiensis), which separate this part of the section into two biostratigraphic subunits between Sections 101-635B-12R-1 and 101-635B12R-2. The subzonal boundary (extinction of $H$. albiensis) occurs in the latest Albian, suggesting that Core 101-635B-8R through Section 101-635B-12R-1 is of latest Albian through early Cenomanian age and Sections 101-635B-12R-2 through 101635B-13R-1 are late Albian in age. Planktonic foraminifers indicate that the entire sequence is late Albian (Planomalina buxtorfi and Biticinella breggiensis Zones) in age. Dinoflagellates, however, suggest that Section 101-635B-8R, CC through Sample 101-635B-11R-2, 134-135 cm, is early Cenomanian. The Cenomanian age assignment of these samples is somewhat dubious, as it is based on nonzonal taxon ranges and stratigraphic correlation with Site 627 (see discussion in Masure, this vol.). The calcareous microplankton fossil assignments, on the other hand, are based on diverse assemblages containing well-documented zonal fossils. As a result, the age assignments based on calcareous nannofossils and planktonic foraminifers are considered to be more reliable and are used herein (Fig. 4). The diverse calcareous microplankton assemblages indicate open-oceanic conditions during deposition. Benthic foraminifers indicate an upper bathyal paleoenvironment.

The sequence from Section 101-635B-13R-2 through Core 101-635B-14R contains calcareous nannofossils from the lower part of the Prediscosphaera columnata Zone (below the first occurrence of Tranolithus phacelosus) and planktonic foraminifers of the Ticinella praeticinensis Zone, indicating a late middle Albian age. The planktonic foraminiferal zonal assignment is based on the occurrence of primitive forms of Biticinella breggiensis, Globigerinelloides gyroidinaeformis, Ticinella primula, Ticinella praeticinensis and the absence of the genus Rotalipora. Occurrences of numerous Braarudosphaera, Corollithion, and Nannoconus suggest neritic influences in the overlying surface waters during deposition, although ostracodes and benthic foraminifers suggest an upper bathyal to outer neritic depth at the site. Sediment gravity-flow structures and inclined bedding indicate a pronounced slope at the site of deposition, suggesting proximity to a shallower area. This may explain the apparent neritic influence in the overlying oceanic surface waters.

\section{CONCLUSIONS}

Sediments from Leg 101 can be divided into five packages based on age and origin: upper Cenozoic skeletal, foraminiferal packstone/grainstone from the Straits of Florida, Neogene and Quaternary periplatform carbonates, upper Cenomanian through 
Oligocene pelagic carbonates, Albian to middle Cenomanian hemipelagic and pelagic mixed clastics/carbonates, and Albian shallow-water platform carbonates and evaporites. Each package has its own paleontological characteristics that aid in deciphering the mid-Cretaceous to Holocene history of the northern Bahamas.

The record from the Straits of Florida (Site 626) is distinct from all others drilled during Leg 101. A discontinuous sequence of winnowed pelagic carbonates from the center of the straits indicates significant bottom-current activity from the late Oligocene to the present. Some periods (such as the latest Oligocene and the early to middle Miocene) were marked by bottom currents sufficiently strong to winnow out most fine-grained material (e.g., calcareous nannofossils) but not strong enough to totally erase the sedimentary record. Other periods (such as the Pliocene and most of the late Miocene) were probably marked by sufficient bottom-current strength to remove the sedimentary record totally.

The Neogene and Quaternary periplatform carbonates record progradation of carbonate slopes north of Little Bahama Bank and in southeastern Exuma Sound. Although uppermost Quaternary sediment is present throughout the northwestern Bahamas, the rest of the Pleistocene record is demonstrably complete only at Site 633. Elsewhere, local unconformities punctuate the sections. A large upper Pliocene unconformity is regionally expressed, indicating a widespread nondepositional/erosional event. Most platform slope progradation occurred during the latest Miocene through early Pliocene, when thick sequences of periplatform sediment accumulated on the slope faces and pro-slope areas. Accumulation at the toe-of-slope was not as appreciable, although it was still elevated from background levels. The early through late (but not latest) Miocene north of Little Bahama Bank was characterized by slower accumulation of periplatform sediments during the late middle Miocene, with significant unconformities in the late Miocene, mid-middle Miocene, and early Miocene.

The Turonian through Oligocene is characterized by intermittent pelagic sedimentation punctuated by major unconformities. Foraminifer-nannofossil ooze is the major lithotype deposited, although siliceous pelagic sedimentation is evident in upper Oligocene (Little Bahama Bank), middle Eocene (Little Bahama Bank and Northeast Providence Channel), and Campanian (Northeast Providence Channel) deposits. The latest Oligocene calcareous planktonic microfossil zones are represented at both Sites 627 and 628 . A relatively complete but not continuous section of Oligocene occurs at Site 628 , although most of the Oligocene is missing from nearby Site 627 . The Paleocene and Eocene are quite condensed and sporadic, having only thin beds of pelagic sediment separated by significant unconformities. In the Cretaceous, only the Campanian is well represented, by thick sections at both Sites 627 (upper Campanian chalk) and 634 (mixed chalk and platform-derived sediment gravity flows). The upper Cenomanian through Santonian is present only at Site 627 , where it is represented by a hardground. Sediment starvation and low surface-water productivity characterized the northwestern Bahamas from the upper Cenomanian through the Oligocene. Only brief pulses of higher surface-water productivity during the late Campanian, middle Eocene, and late Oligocene disrupted this overall pattern.

Mid-Cretaceous hemipelagic and pelagic mixed carbonate/ clastic sediments of Sites 627 and 635 differ greatly in age, texture, and genesis. The uppermost Albian through middle Cenomanian hemipelagic sequence at Site 627 was clearly deposited in a marginally oceanic setting atop a drowned lower Cretaceous carbonate platform. Gradual subsidence and/or sea-level rise resulted in an upward-deepening sequence, and the paleoenvironment changed from middle neritic in the earliest Cenomanian to outer neritic or upper bathyal in the middle Cenomanian. The Albian section from Site 635 is considerably older than that at Site 627 and was deposited in much deeper water. The Site 635 sequence spans the late middle through late (but not latest) Albian, including a substantial unconformity near the base of the section. Bathyal depths are indicated for the entire section, although proximity to neritically influenced surface waters is suggested for the lower part of the section (late middle Albian). This section is time-equivalent to the platform top at Site 627 , indicating that a deep marine channel existed at Site 635 while the platform still thrived at Site 627 .

Shallow-water carbonates and evaporites from Site 627 can be reliably dated as late Albian. Inner neritic, restricted back-reef environments associated with a carbonate platform are suggested by various sedimentological and paleontological indicators.

\section{ACKNOWLEDGMENTS}

Financial support for preparation of this manuscript was supplied by the Ocean Drilling Program (administered through the Texas A\&M Foundation). Use of the facilities of the Department of Geology, University of Nebraska, is gratefully acknowledge. Comments by James A. Austin, Jr., and an anonymous reviewer improved the manuscript and are greatly appreciated.

\section{REFERENCES}

Austin, J. A., Jr., Schlager, W., et al., 1986. Proc. ODP, Init. Repts., 101: College Station, TX (Ocean Drilling Program).

Berggren, W. A., Kent, D. V. and Flynn, J. J., 1985a. Jurassic to Paleogene: Part 2. Paleogene geochronology and chronostratigraphy. In Snelling, N. J., (Ed.), The Chronology of the Geological Record, Memoir 10, the Geological Society: Oxford (Blackwell Scientific), 141-195.

Berggren, W. A., Kent, D. V. and van Couvering, J. A., 1985b. The Neogene: Part 2. Neogene geochronology and chronostratigraphy. In Snelling, N. J. (Ed.), The Chronology of the Geological Record, Memoir 10, the Geological Society: Oxford (Blackwell Scientific), 211-260.

Bolli, H. M., Saunders, J. B., and Perch-Nielsen, K., 1985. Plankton Stratigraphy: Cambridge (Cambridge Univ. Press).

Cepek, P., Köthe, A., Weiss, W., and Wolfart, R., 1985. Paleogeographic evolution of the Atlantic Ocean during the late Cretaceous. Geolog. Jahrb. Reihe B, 62:3-89.

Haq, B. U., Hardenbol, J., and Vail, P. R., 1987. Chronology of fluctuating sea levels since the Triassic (250 million years ago to Present). Science, 235:1156-1167.

Hollister, C. D., Ewing, J. I., et al., 1972. Init. Repts. DSDP, 11: Washington (U.S. Govt. Printing Office).

Leckie, R. M., 1984. Mid-Cretaceous planktonic foraminiferal biostratigraphy off central Morocco, DSDP Leg 79, Sites 545 and 547. In Hinz, K., Winterer, E. L., et al., Init. Repts. DSDP, 79: Washington (U.S. Govt. Printing Office), 579-620.

Palmer, A. R., 1983. The Decade of North American Geology 1983 time scale. Geology, 11:503-504.

Riggs, S. R., 1984, Paleoceanographic model of Neogene phosphorite deposition, U.S. Atlantic continental margin. Science, 223:123-131.

Wilcoxon, J. A., 1972, Calcareous nannoplankton ranges, Leg XI, Deep Sea Drilling Project. In Hollister, C. D., Ewing, J. I., et al., 1972. Init. Repts. DSDP, 11: Washington (U.S. Govt. Printing Office), 459-473.

Date of initial receipt: 15 June 1987

Date of acceptance: 10 September 1987

Ms 101B-170 